\title{
KEMAMPUAN BERPIKIR KRITIS (CRITICAL THINKING) MAHASISWA SEMESTER 4 (EMPAT) PADA MATA KULIAH PSIKOLINGUISTIK
}

\author{
Nahnu Robid Jiwandono \\ Universitas Islam Malang
}

\begin{abstract}
Abstrak
Kemampuan berpikir kritis atau critical thinking merupakan salah satu kemampuan yang sangat penting untuk dikuasai oleh manusia abad 21. Pembelajaran sudah seharusnya diarahkan untuk melatih peserta didik untuk dapat berpikir dengan kritis mengenai suatu masalah. Pembelajaran yang mengajarkan untuk menghafal saja lebih baik mulai diganti dengan menganalisis dan memberikan solusi yang logis. Pada penelitian ini, peneliti berusaha untuk mendapatkan data yang berkaitan dengan hasil tes mahasiswa pada Mata Kuliah Psikolinguistik. Tes yang diujikan sudah dipersiapkan sedemikian rupa dengan karakteristik yang beragam, mulai dari soal yang berkategori $\mathrm{C} 1, \mathrm{C} 2, \mathrm{C} 3, \mathrm{C} 4, \mathrm{C} 5$. Hasil penelitian menunjukkan bahwa karakteristik keterampilan berpikir kritis mahasiswa masih kurang. Terbukti dari hasil penelitian didapatkan bahwa soal HOTS (Higher Order Thinking Skills) yang dikerjakan, sebanyak 57\% masih salah, sedangkan $43 \%$ sudah dijawab dengan benar. Sementara itu, 57\% mahasiswa menjawab soal LOTS (Lower Order Thinking Skills) dengan benar dan $43 \%$ mahasiswa menjawab salah. Dalam hal ini, peneliti menggunakan sumber data berupa hasil tes yang sudah dirancang oleh peneliti dengan subjek penelitian atau subjek uji adalah mahasiswa semester ke-4 tahun 2018.
\end{abstract}

Kata Kunci: berpikir kritis, HOTS, LOTS

\section{PENDAHULUAN}

Kemampuan berpikir kritis (critical thinking) tampaknya menjadi topik menarik yang sedang banyak diperbincangkan di dunia pendidikan saat ini. Pada abad 21 ini, peserta ddik diharapkan dapat terampil untuk dapat menyelesaikan setiap permasalahan dengan kritis dan kreatif. Mereka dituntut untuk dapat dengan kritis memecahkan persoalan dengan daya analisis yang mempertimbangkan berbagai hal yang terkait dengan alasan logis dan inovatif. Berpikir kritis dan kreatif termasuk keterampilan yang diperlukan di abad ke-21 (Bialik \& Fadel, 2015; Scott, 2015b; Griffin \& Care, 2014). Pembelajaran yang hanya sekedar mengahafal teori sudah tidak relevan lagi dengan kebutuhan dan keadaan saat ini. Seluruh aspek kehidupan berkembang sehingga setiap manusia harus kritis dan kreatif dalam menghadapi situasi yang dinamis seperti ini.

Santrock (2007) mendefinisikan berpikir sebagai kemampuan memanipulasi dan mentransformasi informasi dalam memori, dengan tujuan untuk membentuk konsep, alasan, pikiran kritis, dan penyelesaian masalah. Lebih lanjut, berpikir kritis melibatkan cara berpikir introspektif dan produktif, serta mengevaluasi kejadian. Ennis (1985) mendefinisikan berpikir kritis sebagai "reasonable reflective thinking focused on deciding what to believe or do" yang berarti bahwa berpikir kritis merupakan berpikir berdasarkan pertimbangan akal sehat (logika) dan reflektif sebelum memutuskan sesuatu dalam suatu permasalahan. Berdasarkan pendapat ini, dapat disimpulkan bahwa berpikir kritis membutuhkan proses dan pertimbanganpertimbangan sebelum akhirnya seseorang memutuskan atau memberikan penilaian terhadap sesuatu. Tentu pertimbnganpertimbangan itu didasarkan pada alasanalasan yang masuk akal dan sesuai dengan alur berpikir logis. Lebih lanjut, menurut Ennis (1996), perhatian utama pada keterampilan berpikir kritis adalah bagaimana cara seseorang dalam membuat sebuah keputusan terkait suatu hal atau masalah. Pengambilan keputusan ini melibatkan proses penilaian terhadap argumen.

Soal HOTS atau Higher order Thinking Skills merupakan instrumen atau alat pengukuran yang digunakan untuk 
mengukur kemampuan berpikir tingkat tinggi, yaitu kemampuan berpikir yang tidak sekadar mengingat (recall), menyatakan kembali (restate), atau merujuk tanpa melakukan pengolahan (recite). Soalsoal HOTS pada konteks asesmen mengukur kemampuan: 1) transfer satu konsep ke konsep lainnya, 2) memproses dan menerapkan informasi, 3) mencari kaitan dari berbagai informasi yang berbeda-beda, 4) menggunakan informasi untuk menyelesaikan masalah, dan 5) menelaah ide dan informasi secara kritis. Meskipun demikian, soal-soal yang berbasis HOTS tidak berarti soal yang lebih sulit daripada soal recall. Soal HOTS dapat digunakan untuk mengukur kemampuan berpikir kritis atau kemampuan berpikir tingkat tinggi.

Kemampuan berpikir kritis meliputi level kognitif C4 (menganalisis), C5 (mengevaluasi), dan C6 (menciptakan) pada tingkatan kognitif berdasarkan rumusan Anderson (Revisi Teori Bloom). Kemampuan berpikir kritis ini sesuai dengan istilah kemampuan berpikir tingkat tinggi atau HOTS (Higher Order Thinking Skills). Sementara itu, level kognitif C1 (mengingat), $\mathrm{C} 2$ (memahami), dan $\mathrm{C} 3$ (menerapkan) masih digolongkan level LOTS (Lower Order Thinking Skills) atau kemampuan berpikir tingkat rendah.

Pada penelitian ini dirancang atau disusun soal pada mata kuliah psikolinguistik berbentuk pilihan ganda (PG) atau multiple choice (MC). Soal yag disusun sebanyak 22 soal, meliputi: 1 soal kategori $\mathrm{C} 1,2$ soal kategori $\mathrm{C} 2,2$ soal kategori C3, 14 soal kategori C4, dan 3 soal kategori C5. Jumlah Mahasiswa yang terlibat dalam pengambilan data sebagai subjek penelitian sebanyak 23 orang mahasiswa. Mahasiswa menjawab soal berbasis online dengan menggunakan aplikasi Kahoot. Penggunaan aplikasi untuk tes online Kahoot ini digunakan karena mempertimbangkan kefektifan pelaksanaan dan kemudahan dalam evaluasi atau penilaian.

\section{METODE}

Penelitian ini menggunakan pendekatan kualitatif. Sugiono (2017: 15) mendefinisikan penelitian kualitatif sebagai metode penelitian yang berlandaskan pada filsafat postpositivisme, digunakan untuk meneliti pada kondisi objek alamiah, dimana peneliti adalah sebagai instrumen kunci, teknik pengumpulan data dengan triangulasi, analisis data bersifat induktif atau kualitatif, dan hasil penelitian kualitatif lebih menekankan makna daripada generalisasi. Penelitian deskriptif adalah penelitian yang berusaha mendeskripsikan suatu gejala, peristiwa, kejadian yang terjadi saat sekarang dan memusatkan perhatian kepada masalah-masalah aktual sebagaimana adanya pada saat penelitian berlangsung.

Peneliti menggunakan instrumen penelitian berupa tes pilihan ganda yang berjumlah 22 pertanyaan yang memiliki kategori C1 - C5. Persebaran soal berdasarkan kategori kognitif dan level kognitifnya dapat dilihat pada table berikut.

Tabel 1. Persebaran Soal Berdasarkan Kategori Kognitif dan Level Kognitif

\begin{tabular}{|c|c|c|}
\hline $\begin{array}{c}\text { Kategor } \\
\mathbf{i} \\
\text { Kognitif }\end{array}$ & $\begin{array}{c}\text { Level } \\
\text { Kogniti } \\
\mathbf{f}\end{array}$ & Nomor Soal \\
\hline $\mathrm{C} 1$ & \multirow{3}{*}{ LOTS } & 15 \\
$\mathrm{C} 2$ & & 7,9 \\
\hline $\mathrm{C} 3$ & \multirow{3}{*}{ HOTS } & $\begin{array}{c}1,4,5,6,8,11,13,14,16,1 \\
8,19,20,21,22\end{array}$ \\
$\mathrm{C} 4$ & $10,12,17$ \\
\hline
\end{tabular}

\section{HASIL DAN PEMBAHASAN}

Hasil penelitian ini adalah karakteristik kemampuan berpikir kritis pada mahasiswa semester ke-4 pada mata kuliah psikolinguistik. Hasil pengujian menggunakan instrument tes diperoleh tabel yang menunjukkan rekapitulasi jumlah jawaban salah dan jawaban benar sesuai kategori kognitifnya.

Tabel 2. Rekapitulasi jumlah jawaban salah dan benar sesuai kategori kognitif

\begin{tabular}{|c|c|c|c|}
\hline $\begin{array}{c}\text { Kategori } \\
\text { Kognitif }\end{array}$ & $\begin{array}{c}\text { Jumlah } \\
\text { Salah }\end{array}$ & $\begin{array}{c}\text { Jumlah } \\
\text { Benar }\end{array}$ & Jumlah \\
\hline C1 & 9 & 14 & 23 \\
\hline C2 & 15 & 31 & 46 \\
\hline C3 & 26 & 20 & 46 \\
\hline C4 & 186 & 133 & 319 \\
\hline C5 & 36 & 33 & 69 \\
\hline
\end{tabular}


Berdasarkan hasil penelitian, didapatkan persentase jumlah jawaban benar dan salah, baik pada soal kategori HOTS dan LOTS. Perbandingan jumlah jawaban salah dan benar pada soal HOTS dan LOTS dapat dilihat pada Tabel 3.

Tabel 3. Perbandingan Jumlah Jawaban Salah dan Benar pada Soal HOTS dan LOTS

\begin{tabular}{|l|c|c|c|}
\hline Kategori & $\begin{array}{c}\text { Jumlah } \\
\text { Salah }\end{array}$ & $\begin{array}{c}\text { Jumlah } \\
\text { Benar }\end{array}$ & $\begin{array}{c}\text { Jumlah } \\
\text { (Soal) }\end{array}$ \\
\hline LOTS & $\begin{array}{c}50 \\
(43,5 \%)\end{array}$ & $\begin{array}{c}65 \\
(56,5 \%)\end{array}$ & 115 \\
\hline HOTS & $\begin{array}{c}222 \\
(57,2 \%)\end{array}$ & $\begin{array}{c}166 \\
(42,8 \%)\end{array}$ & 388 \\
\hline
\end{tabular}

Hasil penelitian lebih lanjut dapat dilihat pada Diagram 1 dan 2 berikut yang menunjukkan persentase jumlah jawaban benar dan jawaban salah pada soal HOTS dan LOTS. Secara umum, persentase jawaban salah lebih tinggi daripada jawaban benar pada soal HOTS. Sebaliknya, persentase jawaban benar lebih tinggi daripada jawaban salah pada soal LOTS.

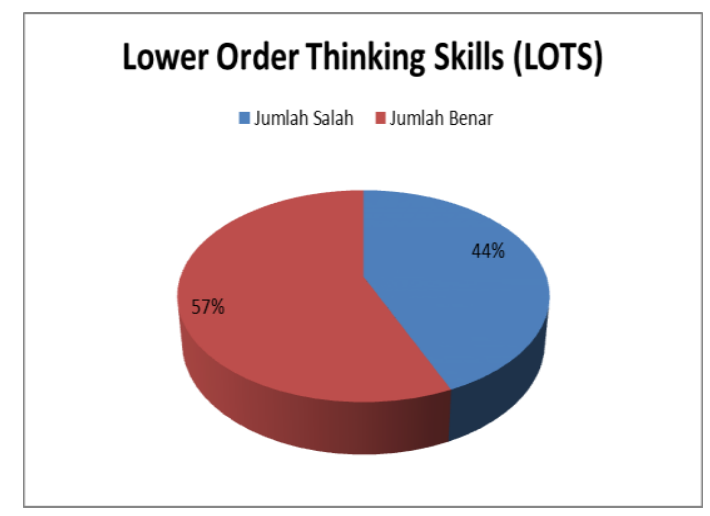

Diagram 1. Persentase Jawaban Benar dan jawaban Salah pada Soal LOTS

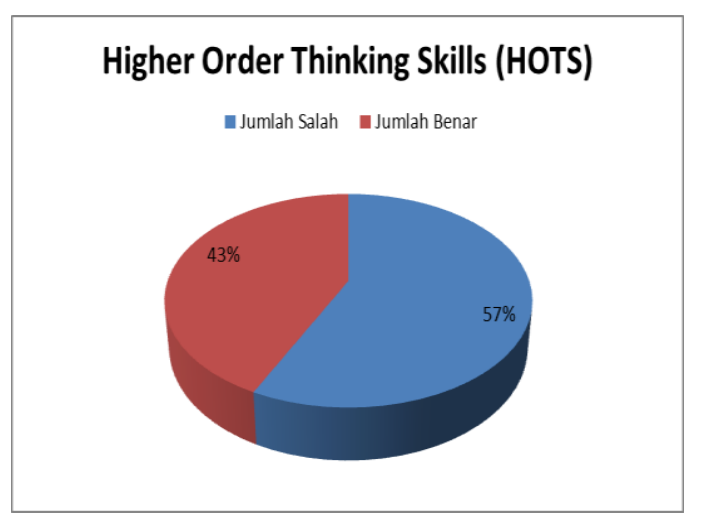

Diagram 2. Persentase Jawaban Benar dan jawaban Salah pada Soal HOTS
Berdasarkan diagram di atas dapat disimpulkan bahwa pada soal HOTS, mahasiswa lebih banyak menjawab salah dibandingkan menjawab dengan benar. Sementara itu, pada soal LOTS lebih banyak jawaban benar dibandingkan jawaban salah. Hal ini menunjukkan bahwa keterampilan berpikir tingkat tinggi atau kemampuan berpikir kritis mahasiswa masih kurang. Hal ini disebabkan karena berbagai faktor, seperti: tidak terbiasa menghadapi soal atau pertanyaan yang menuntut untuk berpikir disertai analisis dan cenderung terbiasa menghadapi pertanyaan hafalan atau ingatan saja.

\section{SIMPULAN}

Berdasarkan pembahasan dan hasil penelitian yang telah dipaparkan di atas, dapat disumpulkan bahwa kemampuan berpikir kritis mahasiswa masih dalam kategori kurang, hal ini terlihat dari kemampuan mahasiswa yang menjawab soal berkategori HOTS masih di bawah $50 \%$. Sementara itu, kemampuan mahasiswa dalam menjawab soal LOTS sudah cukup baik, terlihat dari jumlah jawaban benar yang mencapai lebih dari $50 \%$. Peneliti berharap banyak peneliti lain yang melakukan kajian atau penelitian terkait kemampuan berpikir kritis atau critical thinking peserta didik pada pembelajaran di tingkat pendidikan tinggi maupun di bawahnya, seperti: pendidikan menengah atas, pendidikan menengah pertama, bahkan pendidikan dasar. Selain itu, mengingat pentingnya kemampuan berpikir kritis pada kehidupan abad 21 ini, para pengajar atau pendidik sudah sepatutnya membiasakan untuk melatih kemampuan berpikir kritis pada setiap kegiatan pembelajaran agar peserta didik terbiasa mampu menyelesaikan permasalahan secara dengan kritis dan kreatif. 


\section{DAFTAR PUSTAKA}

Bialik, M. \& Fadel, C. 2015. Skills for the 21st Century: What Should Students Learn? Center for Curriculum Redesign. Boston, Massachusetts.

Ennis, Robert. 1985. The Logical Basis for Measuring Critical Thinking Skills. Educational Leadership. 43(2), 44-48.

Ennis, R.H. 1996. Critical thinking. Upper Saddle River, NJ: Prentice-Hall.

Griffin, P. \& Care, E. 2014. Developing Learners' Collaborative Problem Solving Skills. European Schoolnet Academy \& KeyCoNe.
Santrock, J.W. 2007. Perkembangan Anak. Terjemahan Mila rachmawati \& Anna Kuswanti. Jakarta: Penerbit Erlangga. Tanpa tahun.

Scott, C.L. 2015. The Futures of Learning 2: What kind of learning for the 21st century? Paris, UNESCO Education Research and Foresight. [ERF Working Papers Series, No. 14.

Kementerian Pendidikan dan Kebudayaan. 2017. Modul Penyusunan Soal Higher Order Thinking Skill (HOTS).

Jakarta: Direktorat Jenderal Pendidikan Dasar dan Menengah. 